\title{
ANALISIS DISIPLIN KERJA DAN SARANA PRASARANA TERHADAP PRODUKTIVITAS KERJA PEGAWAI PADA DINAS PERIKANAN KABUPATEN TULANG BAWANG
}

\author{
Nuraeni, Hazairin Habe \\ Universitas Sang Bumi Ruwa Jurai \\ nuraeni@saburai.ac.id,hajairin@saburai.ac.id
}

\begin{abstract}
Abstrak. Penelitian ini bertujuan untuk mengetahui pengaruh disiplin dan sarana prasarana terhadap produktivitas kerja. Sampel yang digunakan pada penelitian ini berjumlah 66 pegawai. Metode pengumpulan data berupa data primer dan data sekunder dengan teknik pengumpulan data meliputi kegiatan observasi, dokumentasi dan angket. Metode analisis data menggunakan pendekatan kuantitatif dengan bantuan alat statistik SPSS versi 21.0 meliputi perhitungan uji validitas, uji reliabilitas, uji regresi linier sederhana dan berganda, uji t, uji $\mathrm{F}$ dan uji koefisien determinasi. Hasil pengujian hipotesis pengaruh disiplin terhadap produktivitas kerja secara parsial menunjukkan pengaruh positif dengan kontribusi sebesar $32,8 \%$. Sarana prasarana secara parsial berpengaruh positif terhadap produktivitas kerja dengan kontribusi sebesar $13,7 \%$. Pengujian hipotesis secara simultan menunjukkan bahwa variabel bebas disiplin dan sarana prasarana secara bersamasama berpengaruh secara positif terhadap variabel terikat produktivitas kerja dengan kontribusi sebesar $36 \%$, sedangkan sisanya sebesar $64 \%$ merupakan variasi variabel lain yang tidak diteliti, seperti motivasi, kepemimpinan, budaya kerja dan lain sebagainya.
\end{abstract}

Kata kunci: Disiplin, Sarana Prasarana, Produktivitas Kerja

\section{ANALYSIS OF WORK DISCIPLINE AND INFRASTRUCTURE ON EMPLOYEE WORK PRODUCTIVITY AT THE FISHERIES OFFICE OF TULANG BAWANG REGENCY}

\author{
Nuraeni, Hazairin Habe \\ Sang Bumi Ruwa Jurai University \\ nuraeni@saburai.ac.id,hajairin@saburai.ac.id
}

\begin{abstract}
This study aims to determine the effect of discipline and infrastructure on work productivity. The sample used in this study amounted to 66 employees. Data collection methods in the form of primary data and secondary data with data collection techniques include observation, documentation and questionnaires. The data analysis method used a quantitative approach with the help of SPSS version 21.0 statistical tools including the calculation of the validity test, reliability test, simple and multiple linear regression, $t$ test, $F$ test and coefficient of determination test. The results of hypothesis testing the influence of discipline on work productivity partially show a positive effect with a contribution of $32.8 \%$. Infrastructure partially has a positive effect on work productivity with a contribution of $13.7 \%$. Simultaneous hypothesis testing shows that the independent variabels of discipline and infrastructure together have a positive effect on the dependent variabel of work productivity with a contribution of $36 \%$, while the remaining $64 \%$ is a variation of other variabels not examined, such as motivation, leadership, work culture and others. etc.
\end{abstract}

Keywords: Discipline, Infrastructure, Work Productivity 


\section{PENDAHULUAN}

Setiap organisasi pastilah memiliki tujuan dan sasaran untuk dicapai, dimana hal itu akan sangat tergantung pada bagaimana organisasi tersebut dapat mengembangkan kemampuannya, baik secara teknis maupun manajerial (E. Ningrum, 2016). Oleh karena itu, seharusnya sumber daya manusia (SDM) mendapatkan perhatian dari pihak manajerial terutama pimpinan (N. Saputra \& Mulia, 2020). Kebijakan yang berkaitan dengan pengelolaan SDM, mulai dari proses penarikan, penempatan, pemeliharaan, pengembangan sampai dengan tujuan untuk meningkatkan keandalan sumber daya manusia yang merupakan faktor penting faktor penting yang membuat individu dan organisasi siap menghadapi perubahan (Prianto et al., 2020).

Organisasi menuntut tercapainya kinerja yang tinggi dari pegawainya untuk dapat menunjang kelancaran kegiatan, sehingga tujuan organisasi dapat tercapai secara optimal (M. E. Ningrum, 2013). Namun setiap pegawai memiliki kinerja yang berbeda-beda, yang selanjutnya akan dapat mempengaruhi tingkat produktivitas (Fithri \& Sari, 2016).

Berdasarkan pengamatan lapangan dapat terindikasi bahwa ada beberapa faktor yang mempengaruhi produktivitas kerja pegawai, antara lain adalah disiplin kerja. Disiplin merupakan keadaan ideal dalam mendukung pelaksanaan tugas sesuai aturan dalam rangka mendukung optimalisasi kerja (Effendy \& Fitria, 2020; Kamal, 2015). Pegawai Negeri Sipil (PNS) yang tidak melakukan kewajiban dan melakukan perbuatan yang dilarang sebagaimana diatur dalam Peraturan Pemerintah No. 53 Tahun 2010, dianggap telah melakukan pelanggaran disiplin PNS (Sandiani et al.,
2020) dan tentu saja harus mendapatkan hukuman disiplin. Tujuan hukuman disiplin Pegawai Negeri Sipil adalah untuk memperbaiki dan mendidik Pegawai Negeri Sipil yang melakukan pelanggaran disiplin (Alexander, 2020). Namun pada kenyataannya permasalahan disiplin pegawai ini menghadapi hambatan dan tantangan dalam pelaksanaannya, yaitu berupa ketegasan pimpinan dalam menjatuhkan sanksi kepada pelanggar karena Ketegasan pimpinan tersebut akan mempengaruhi kedisiplinan (Suryani \& Maulana, 2019).

Dinas Perikanan Kabupaten Tulang Bawang dalam upaya mendorong produktivitas kerja pegawainya dihadapkan pada permasalahan disiplin pegawai berkaitan dengan ketidakhadiran pegawai, kesadaran pegawai dalam menjalankan tugas serta tanggungjawab pekerjaan yang diberikan (Herdin \& Suyitno, 2016), dan kurangnya rangsangan dalam melaksanakan pekerjaan sesuai dengan Tupoksi (Sulastriningsih \& Novita, 2016). Berdasarkan hasil observasi yang dilakukan di lokasi penelitian, penulis menemukan data kehadiran pegawai tahun 2019, sebagai berikut :

Tabel 1

Persentase Kehadiran Pegawai Tahun 2019

\begin{tabular}{clcc}
\hline No. & Bulan & $\begin{array}{c}\text { Target } \\
(\%)\end{array}$ & $\begin{array}{c}\text { Realisasi } \\
(\%)\end{array}$ \\
\hline 1. & Januari & 100 & 73 \\
2. & Februari & 100 & 75 \\
3. & Maret & 100 & 84 \\
4. & April & 100 & 84 \\
5. & Mei & 100 & 75 \\
6. & Juni & 100 & 83 \\
7. & Juli & 100 & 78 \\
8. & Agustus & 100 & 84 \\
9. & September & 100 & 76 \\
10. & Oktober & 100 & 76 \\
11. & November & 100 & 75 \\
12. & Desember & 100 & 73 \\
\hline \multicolumn{5}{c}{ Rata-Rata } & 100 & 78 & \\
\hline \multicolumn{5}{c}{ Sumber: Dinas } & Perikanan & kabupaten & Tulang \\
Bawang, 2019 & & &
\end{tabular}


Berdasarkan tabel di atas, selama kurun waktu tahun 2019 tingkat kehadiran pegawai tidak pernah mencapai angka $100 \%$ setiap bulannya, dengan capaian ratarata kehadiran hanya sebesar $78 \%$ saja.

Faktor lain yang turut mempengaruhi produktivitas kerja pegawai adalah sarana prasarana. Sarana adalah segala sesuatu yang dapat dipakai sebagai alat dalam mencapai maksud dan tujuan (Nooraeni, 2017). Sedangkan prasarana adalah segala sesuatu yang merupakan penunjang utama terselenggaranya suatu proses usaha, pembangunan, proyek, dan sebagainya (Ellong, 2018). Antara sarana dan prasarana tidak terlalu jauh berbeda (Amaliah, 2019), karena keduanya saling berkaitan dan tidak dapat dipisahkan. Permasalahan yang timbul pada Dinas Perikanan Kabupaten Tulang Bawang adalah ketersediaan sarana prasarana yang minim dalam mendukung aktivitas pegawai, seperti jumlah kendaraan dinas yang masih belum sesuai dengan luas wilayah kerja, sebagaimana ditnjukkan oleh tabel berikut:

Tabel 2

Daftar Inventaris Sarana Kendaraan Dinas Perikanan Kabupaten Tulang Bawang Tahun 2019

\begin{tabular}{|c|c|c|c|c|c|}
\hline \multirow{2}{*}{ No } & \multirow{2}{*}{$\begin{array}{c}\text { Kendaraa } \\
\mathrm{n} \\
\text { Bermotor }\end{array}$} & \multirow{2}{*}{$\underset{\mathrm{h}}{\text { Jumla }}$} & \multicolumn{2}{|c|}{ Kondisi } & \multirow[b]{2}{*}{ Ket. } \\
\hline & & & $\begin{array}{c}\text { Bai } \\
\mathrm{k}\end{array}$ & $\begin{array}{l}\text { Kuran } \\
\text { g Baik }\end{array}$ & \\
\hline 1. & $\begin{array}{l}\text { Ranmor } \\
\text { Minibus } \\
\text { R4 } \\
\text { (Strada) }\end{array}$ & 2 & $\checkmark$ & & - \\
\hline 2. & $\begin{array}{l}\text { Ranmor } \\
\text { Minibus } \\
\text { R4 } \\
\text { (Panther) }\end{array}$ & 1 & $\checkmark$ & & - \\
\hline 3. & $\begin{array}{l}\text { Ranmor } \\
\text { Pickup R4 } \\
\text { (Panther) }\end{array}$ & 1 & & $\checkmark$ & $\begin{array}{c}\text { Rusa } \\
\text { k } \\
\text { Berat }\end{array}$ \\
\hline 4. & $\begin{array}{l}\text { Ranmor } \\
\text { R2 }\end{array}$ & 18 & $\checkmark$ & & - \\
\hline 5. & $\begin{array}{l}\text { Speed } \\
\text { Boat }\end{array}$ & 2 & $\checkmark$ & & - \\
\hline & Rata-Rata & 24 & & & \\
\hline
\end{tabular}

Sumber: Laporan Kinerja Dinas Perikanan kabupaten Tulang Bawang, 2019

Tabel di atas menunjukkan bahwa jumlah keseluruhan kendaraan dinas adalah 24 unit, terdiri dari 4 unit kendaraan roda 4 dengan kondisi 1 unit rusak berat. Kendaraan roda 2 berjumlah 18 unit serta alat transportasi air sejumlah 2 unit. Melihat kondisi kualitas dan kuantitas kendaraan dinas sebagaimana tabel di atas, maka dapat dikatakan belum dapat memenuhi kebutuhan pegawai Dinas Perikanan Kabupaten Tulang Bawang dalam menjalankan tugas dan pekerjaan mengingat luas wilayah kerja pada Kabupaten Tulang Bawang yaitu seluas $4.386 \mathrm{~km}^{2}$.

Permasalahan disiplin kerja dan keterbatasan sarana prasarana sebagaimana diuraikan di atas menjadi salah satu penyebab rendahya produktivitas kerja pegawai pada Dinas Perikanan Kabupaten Tulang Bawang. Hal ini diindikasikan oleh realita yaitu masih ada program kegiatan yang belum terealisasi $100 \%$ pada Tahun Anggaran 2019, sebagaimana tabel berikut:

Tabel 3

Program Kerja yang tidak tercapai $100 \%$ di Tahun Anggaran 2019

\begin{tabular}{|c|c|c|c|}
\hline No. & Program & $\begin{array}{c}\text { Target } \\
(\%)\end{array}$ & $\begin{array}{c}\text { Realisasi } \\
(\%)\end{array}$ \\
\hline 1. & $\begin{array}{l}\text { Optimalisasi } \\
\text { Pengelolaan dan } \\
\text { Pemasaran } \\
\text { Produksi } \\
\text { Perikanan }\end{array}$ & 90 & 78,12 \\
\hline 2. & $\begin{array}{l}\text { Pengembangan } \\
\text { Kawasan } \\
\text { Budidaya Laut, } \\
\text { Air Payau, dan } \\
\text { Air Tawar }\end{array}$ & 85 & 73,2 \\
\hline 3. & $\begin{array}{l}\text { Pengembangan } \\
\text { Sektor Perikanan } \\
\text { Melalui } \\
\text { Percepatan } \\
\text { Operasional Balai } \\
\text { Benih Ikan (BBI) }\end{array}$ & 85 & 70,93 \\
\hline
\end{tabular}


Data faktual capaian program ini mengindikasikan bahwa produktivitas pegawai Dinas Perikanan Kabupaten Tulang Bawang masih belum sesuai harapan. Pencapaian target program kerja ini lebih banyak disebabkan oleh penyelesaian pekerjaan tidak tepat waktu (Hassan et al., 2016), hal tersebut mengingat keterbatasan sarana prasarana berupa kendaraan dinas yang jumlahnya tidak sesuai dengan kebutuhan, ditambah lagi dengan permasalahan tingkat kehadiran disiplin kerja pegawai belum maksimal (Dewi et al., 2018).

Penelitian sejenis mengenai pengaruh disiplin kerja sudah pernah dilakukan, antara lain oleh Andini, et. al mengenai pengaruh disiplin kerja terhadap produktivitas kerja (Andini et al., 2019). Penelitian oleh Saleh \& Utomo mengenai pengaruh disiplin kerja, motivasi kerja, etos kerja, dan lingkungan kerja terhadap produktivitas kerja (Saleh \& Utomo, 2018). Penelitian oleh Radito mengenai Disiplin kerja, lingkungan kerja, dan Jaminan sosial terhadap produktivitas kerja (Radito, 2016). Selain itu, penelitian mengenai pengaruh sarana prasarana juga sudah pernah dilakukan, antara lain: penelitian oleh Nisa mengenai Pengaruh kualitas SDM dan Sarana Prasarana terhadap produktivitas Kerja (Nisa, 2017) dan hubungan pengelolaan Sarana dan Prasarana berbasis IT terhadap peningkatan Produktivitas kerja (Sulistya \& Zain, 2020).

Berdasarkan dari beberapa penelitian yang sudah dilakukan, belum pernah diadakan penelitian yang melihat pengaruh Disiplin dan Sarana Prasarana terhadap Produktivitas Kerja. Oleh karena itu, peneliti mengangkat hal tersebut sebagai unsur kebaruan dalam penelitian ini. Maka penelitian ini bertujuan untuk melihat pengaruh Disiplin Pegawai dan Sarana Prasarana terhadap Produktivitas kerja
Pegawai pada Dinas Perikanan Kabupaten Tulang Bawang.

\section{TINJAUAN TEORITIS}

\section{Disiplin}

Disiplin di dalam pekerjaan
mencerminkan rasa tanggung jawab sesorang terhadap tugas-tugas yang diberikan (Tanjung, 2015). Disiplin kerja adalah suatu kondisi dalam organisasi dimana para pegawai menampilkan dirinya masing - masing sesuai peraturan organisasi dan standar perilaku yang dapat diterima. Desler (2002) menjabarkan jika disiplin kerja sebagai suatu prosedur yang mengoreksi atau menghukum seorang bawahan karena melanggar aturan atau prosedur (Hartanto et al., 2018).

Disiplin yang datang dari individu sendiri adalah disiplin yang berdasarkan atas kesadaran individu sendiri dan bersifat spontan. Disiplin ini merupakan disiplin yang sangat diharapkan oleh suatu organisasi karena disiplin ini tidak memerlukan perintah atau teguran langsung. Sedangkan yang dimaksud dengan disiplin berdasarkan perintah yakni dijalankan karena adanya sanksi atau ancaman hukuman. Dengan demikian orang yang melaksanakan disiplin ini karena takut terkena sanksi atau hukuman, sehingga disiplin dianggap sebagai alat untuk menuntut pelaksanaan tanggung jawab. Bertitik tolak dari uraian tersebut dapat disimpulkan bahwa inti dari pembentukan disiplin dapat dilaksanakan melalui dua cara, yaitu melalui pengembangan disiplin pribadi atau pengembangan disiplin yang datang dari individu serta melalui penerapan tindakan disiplin yang ketat, artinya bagi seorang pegawai yang indisipliner akan dikenai hukuman atau 
sanksi sesuai dengan tingkatan kesalahan (Mahrita et al., 2018).

Ada dua macam disiplin kerja menurut Keith Davis, yaitu disiplin preventif dan disiplin korektif (A. Saputra \& Turnip, 2018). Disiplin preventif adalah suatu upaya untuk menggerakkan pegawai untuk mengikuti dan mematuhi pedoman dan aturan kerja yang ditetapkan oleh organisasi (Riyanto, 2019). Tujuan dasarnya adalah untuk menggerakkan pegawai berdisiplin diri. Dengan cara preventif, pegawai dapat memelihara dirinya terhadap peraturan-peraturan organisasi (Adiwilaga, 2019). Disiplin Korektif adalah upaya penggerakkan pegawai dalam menyatukan suatu peraturan dan mengarahkannya agar tetap mematuhi berbagai peraturan sesuai dengan pedoman yang berlaku pada organisasi (Riyanto, 2019). Pada disiplin korektif, pegawai yang melanggar disiplin perlu diberikan sanksi sesuai dengan peraturan yang berlaku. Tujuan pemberian sanksi adalah untuk memperbaiki pegawai pelanggar, memelihara peraturan yang berlaku, dan memberikan pelajaran kepada pelanggar (Jannah et al., 2014).

Ada tiga pendekatan disiplin, yaitu pendekatan disiplin modern, disiplin dengan tradisi, dan disiplin bertujuan (Yanti et al., 2015). Pendekatan Disiplin Modern, yaitu mempertemukan sejumlah keperluan atau kebutuhan baru di luar hukuman (Husna, 2017). Disiplin modern merupakan suatu cara menghindarkan bentuk hukuman secara fisik; Melindungi tuduhan yang benar untuk diteruskan pada proses hukum yang berlaku; Keputusan keputusan yang semaunya terhadap kesalahan atau prasangka harus diperbaiki dengan mengadakan proses penyuluhan dengan mendapatkan fakta-faktanya; Melakukan protes terhadap keputusan yang berat sebelah pihak terhadap kasus disiplin (Putri \& Sukirno, 2020).
Pendekatan Disiplin dengan Tradisi, yaitu pendekatan disiplin dengan cara memberikan hukuman (Daulay et al., 2019). Pendekatan Disiplin Bertujuan, Pendekatan disiplin bertujuan berasumsi bahwa: Disiplin kerja harus dapat diterima dan dipahami oleh semua pegawai; Disiplin bukanlah suatu hukuman, tetapi merupakan pembentukan perilaku; Disiplin ditujukan untuk perubahan perilaku yang lebih baik; Disiplin pegawai bertujuan agar pegawai bertanggungjawab terhadap perbuatannya (Yanti et al., 2015).

\section{Sarana dan Prasarana Kantor}

Menurut Kamus Besar Bahasa Indonesia (KBBI), Sarana adalah segala sesuatu yang dapat dipakai sebagai alat dalam mencapai maksud dan tujuan. Prasarana adalah segala sesuatu yang merupakan penunjang utama terselenggaranya suatu proses (usaha, pembangunan, proyek) (Rakhman, 2019). Antara sarana dan prasarana tidak terlalu jauh berbeda, karena keduanya saling berkaitan dan tidak dapat dipisahkan. Untuk membedakannya, sarana lebih ditujukan kepada benda - benda yang bergerak, sedangkan prasarana lebih ditujukan untuk benda-benda yang tidak bergerak (Amaliah, 2019).

Berdasarkan Peraturan Menteri Dalam Negeri Nomor 7 Tahun 2006, Sarana kerja adalah fasilitas yang secara langsung berfungsi sebagai penunjang proses penyelenggaraan pemerintahan daerah dalam mencapai sasaran yang ditetapkan, antara lain; ruangan kantor, perlengkapan kerja, dan kendaraan dinas (Richiyanti, 2019). Prasarana kerja adalah fasilitas yang secara tidak langsung berfungsi menunjang terselenggaranya suatu proses kerja aparatur dalam meningkatkan kinerja sesuai dengan tugas dan tanggung jawabnya, seperti gedung kantor, rumah jabatan dan rumah instansi 
(Hadi \& Abdurrahman, 2019). Berdasarkan peraturan menteri tersebut maka yang dimaksud dengan sarana dan prasarana adalah fasilitas yang secara langsung ataupun tidak langsung berfungsi sebagai proses penyelenggaraan pemerintahan daerah dalam mencapai sasaran yang telah ditetapkan.

\section{Produktivitas Kerja}

Produktivitas kerja merupakan konsep yang bersifat universal yang merupakan efektivitas operasional suatu organisasi, bagian organisasi dan bagian karyawannya berdasar standar dan kriteria yang telah ditetapkan sebelumnya, karena organisasi pada dasarnya dijalankan oleh manusia, maka produktivitas kerja sesungguhnya merupakan perilaku manusia dalam memainkan peran yang mereka lakukan dalam suatu organisasi untuk memenuhi standar perilaku yang telah ditetapkan agar membuahkan tindakan dan hasil yang diinginkan (Sholiha et al., 2017).

Produktivitas kerja merupakan hasil kerja yang dihasilkan oleh pegawai atau perilaku nyata yang ditampilkan sesuai peranannya dalam organisasi. Produktivitas kerja juga berarti hasil yang dicapai seseorang baik kualitas maupun kuantitas sesuai dengan tanggungjawab yang diberikan kepadanya (Adha et al., 2019). Selain itu produktivitas kerja seseorang dipengaruhi oleh tingkat pendidikan, inisiatif, pengalaman kerja, dan motivasi karyawan (Wijayanti \& Sundiman, 2017). Hasil kerja seseorang akan memberikan umpan balik bagi orang itu sendiri untuk selalu aktif melakukan pekerjaannya secara baik dan diharapkan akan menghasilkan mutu pekerjaan yang baik pula. Pendidikan mempengaruhi produktivitas kerja seseorang karena dapat memberikan wawasan yang lebih luas untuk berinisiatif dan berinovasi dan selanjutnya berpengaruh terhadap kinerjanya (Bili et al., 2018).
Deskripsi dari produktivitas kerja menyangkut tiga komponen penting yaitu: 1) Tujuan; 2) Ukuran, dan 3) Penilaian (Karollah, 2017). Manfaat produktivitas kerja pegawai antara lain adalah untuk menganalisa dan mendorong efisiensi produksi, untuk menentukan target atau sasaran yang nyata, lalu untuk pertukaran informasi antara tenaga kerja dan manajemen yang berhubungan terhadap masalah-masalah yang berkaitan (Purwati \& Nugraha, 2018).

\section{METODE PENELITIAN}

Metode penelitian yang digunakan adalah metode kuantitatif. Objek penelitian ini adalah permasalahan disiplin kerja, sarana prasarana dan produktivitas pegawai pada Dinas Perikanan Kabupaten Tulang Bawang. Dengan demikian populasi dalam penelitian ini adalah seluruh pegawai yang ada di Dinas Perikanan Kabupaten Tulang Bawang. Dalam penelitian ini jumlah populasi di lingkungan Dinas Perikanan Kabupaten Tulang Bawang sebesar 67 pegawai. Berdasarkan hal ini, maka sampel yang digunakan berjumlah seluruh populasi dikurangi satu orang yaitu peneliti, sehingga ditentukan sebanyak 66 pegawai. Penentuan sampel dalam penelitian ini, penulis merujuk pendapat Arikunto (2012:101), yang menyatakan apabila dalam suatu penelitian terhadap subjek yang kurang dari 100, maka populasi akan diambil seluruhnya sebagai sampel.

Teknik pengumpulan data yaitu Metode kuesioner/angket, dokumentasi, dan observasi. Pengolahan data statistik dalam penelitian ini dengan menggunakan aplikasi SPSS. Agar dapat memperoleh data dari responden dengan baik, kuesioner sebagai instrumen pengumpulan data penelitian harus memenuhi persyaratan validitas dan reliabilitas. Untuk itu, kuesioner tersebut harus diuji terlebih dahulu tingkat validitas 
dan reliabilitasnya. Teknik analisis data menggunakan analisis regresi untuk mengetahui pengaruh hubungan (asoisasi) antara dua variabel yakni variabel $X$ (independen) dan variabel Y (dependen), dimana terdapat 2 variabel independent yaitu Disiplin Kerja (X1) dan Sarana Prasarana (X2) serta 1 variabel dependen yaitu Produktivitas Kerja (Y).

\section{HASIL DAN PEMBAHASAN}

Berdasarkan data yang telah didapat, jawaban responden direkapitulasi kemudian dianalisis untuk mengetahui pengaruh dari variabel-variabel yang dilihat. Sebelum itu, berikut hasilnya :

\section{Pengaruh Disiplin Kerja terhadap Produktivitas Kerja}

Pengujian pengaruh disiplin kerja secara parsial terhadap produktivitas kerja pegawai Dinas Perikanan Kabupaten Tulang Bawang digunakan uji statistic t (uji t) dengan hipotesis sebagai berikut:

$\mathrm{H}_{\mathrm{o}}$ : Disiplin Kerja (X1) tidak berpengaruh terhadap Produktivitas kerja (Y) Dinas Perikanan Kabupaten Tulang Bawang.

$\mathrm{H}_{\mathrm{a}}$ : Disiplin Kerja (X1) berpengaruh terhadap Produktivitas kerja (Y) Dinas Perikanan Kabupaten Tulang Bawang. SPSS:

Berikut hasil analisis dari software

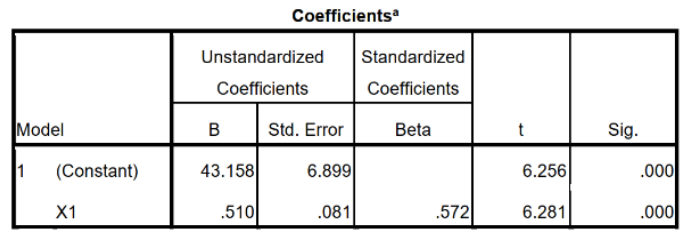

a. Dependent Variable: Produktivitas

kerja.Y

Gambar 1. Pengujian Hipotesis Parsial Disiplin Kerja terhadap Produktivitas Kerja
Berdasarkan Gambar 1 di atas, diperoleh nilai $\mathrm{Sig}=0,000<0,05 . \mathrm{H}_{\mathrm{o}}$ ditolak dan $\mathrm{H}_{\mathrm{a}}$ diterima, yang artinya Disiplin Kerja (X1) berpengaruh terhadap Produktivitas kerja (Y) Dinas Perikanan Kabupaten Tulang Bawang.

Hasil koefisien arah regresi antara disiplin kerja terhadap produktivitas kerja pegawai sebesar 0.510 dengan konstanta menunjukkan nilai positif sebesar 43.158. Dengan demikian, persamaan regresinya adalah $Y=43.158+0.510 X_{1}$. Artinya, bahwa setiap kenaikan disiplin kerja 1 satuan akan diikuti dengan kenaikan produktivitas kerja pegawai sebesar 0.510 satuan. Sebaliknya, jika disiplin kerja mengalami penurunan sebesar 1 satuan maka produktivitas kerja pegawai mengalami penurunan sebesar 0.510 satuan dan nilai koefisien a (intercept) adalah sebesar 43.158 yang berarti apabila tidak terdapat disiplin kerja $\left(X_{1}=0\right)$, diperkirakan produktivitas kerja pegawai tetap sebesar 43.158 satuan.

Seberapa jauh variabel ini dapat menjelaskan variabel produktivitas kerja dapat dilihat dari nilai koefisien determinasi ( $R$ Square) pada gambar berikut.

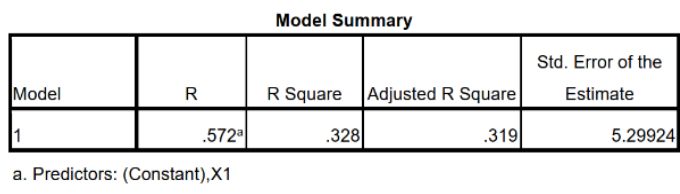

Gambar 2. Hasil Uji Koefisien Determinasi

Gambar 2 di atas menjelaskan bahwa $R$ Square sebesar 0.328 yang artinya sebesar $32.8 \%$ variasi perubahan variabel produktivitas kerja mampu dijelaskan oleh variabel disiplin kerja sedangkan sisanya yaitu $67.2 \%$ lagi dijelaskan faktor-faktor lain yang tidak diteliti dalam penelitian ini.

\section{Pengaruh Sarana Prasarana terhadap Produktivitas Kerja}


Pengujian pengaruh variabel sarana prasarana secara parsial terhadap produktivitas kerja pegawai Dinas Perikanan Kabupaten Tulang Bawang digunakan uji statistic $t$ (uji t) dengan hipotesis sebagai berikut:

$\mathrm{H}_{\mathrm{o}}$ : Sarana Prasarana (X2) tidak berpengaruh terhadap Produktivitas kerja (Y) Dinas Perikanan Kabupaten Tulang Bawang.

$\mathrm{H}_{\mathrm{a}}$ : Sarana Prasarana (X2) berpengaruh terhadap Produktivitas kerja (Y) Dinas Perikanan Kabupaten Tulang Bawang.

Berikut hasil analisis dari software SPSS:

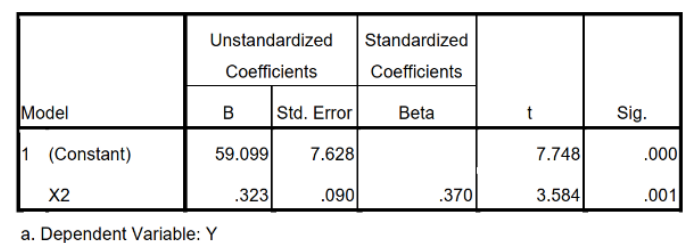

Gambar 3. Pengujian Hipotesis Parsial Sarana Prasarana terhadap Produktivitas Kerja

Berdasarkan Gambar 3 di atas, diperoleh nilai $\mathrm{Sig}=0,001<0,05 . \mathrm{H}_{\mathrm{o}}$ ditolak dan $\mathrm{H}_{\mathrm{a}}$ diterima, yang artinya Sarana Prasarana (X2) berpengaruh terhadap Produktivitas kerja (Y) Dinas Perikanan Kabupaten Tulang Bawang.

Hasil koefisien arah regresi antara Sarana Prasarana terhadap produktivitas kerja pegawai menunjukkan nilai positif sebesar 0.323 dengan konstanta sebesar 59.099. Dengan demikian, persamaan regresinya adalah $Y=59.099+0.323 X_{2}$. Artinya, bahwa setiap kenaikan Sarana Prasarana 1 satuan akan diikuti dengan kenaikan produktivitas kerja pegawai sebesar 0.323 satuan. Sebaliknya, jika disiplin kerja mengalami penurunan sebesar 1 satuan maka produktivitas kerja pegawai mengalami penurunan sebesar 0,323 satuan dan nilai koefisien a (intercept) adalah sebesar 59.099 yang berarti apabila tidak terdapat disiplin kerja $\left(X_{2}=0\right)$, diperkirakan produktivitas kerja pegawai tetap sebesar 59.099 satuan.

Seberapa jauh variabel ini dapat menjelaskan variabel produktivitas kerja dapat dilihat dari nilai koefisien determinasi ( $R$ Square) pada gambar berikut.

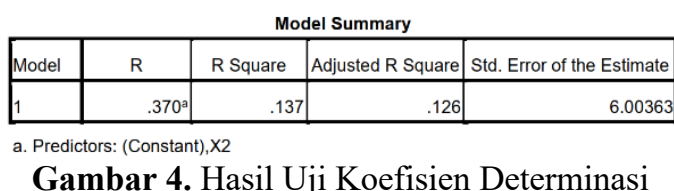

Gambar 4 di atas menjelaskan bahwa $R$ Square sebesar 0.137 yang artinya sebesar $13.7 \%$ variasi perubahan variabel produktivitas kerja mampu dijelaskan oleh variabel Sarana Prasarana sedangkan sisanya yaitu $86.3 \%$ lagi dijelaskan faktorfaktor lain yang tidak diteliti dalam penelitian ini.

\section{Pengaruh Disiplin Kerja dan Sarana Prasarana secara Simultan terhadap Produktivitas Kerja}

Pengujian pengaruh variabel Disiplin kerja dan sarana prasarana secara simultan terhadap produktivitas kerja pegawai Dinas Perikanan Kabupaten Tulang Bawang digunakan uji F. sebelum melakukan Uji F, peneliti melakukan perhitungan regresi berganda untuk mengevaluasi hubungan antara suatu variabel dependent dengan satu atau lebih variabel independent. Berikut hasilnya:

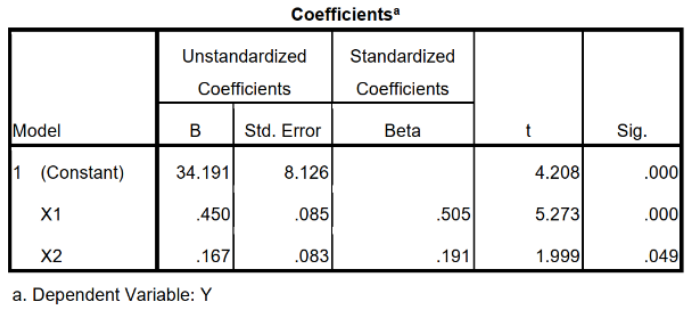

Gambar 5. Perhitungan Regresi Berganda

Dari Gambar 5 dapat disimpulkan bahwa nilai koefisien dari kedua variabel 
(X1 dan X2) menunjukkan nilai yang positif. Setelah melihat hasil perhitungan regresi berganda, dilanjutkan Uji $\mathrm{F}$ untuk mengetahui apakah semua variabel independen secara bersama-sama mempunyai pengaruh yang signifikan terhadap variabel dependen dengan hipotesis sebagai berikut:

$\mathrm{H}_{\mathrm{o}}$ : Disiplin Kerja (X1) dan Sarana Prasarana (X2) tidak berpengaruh secara simultan terhadap Produktivitas kerja (Y) Dinas Perikanan Kabupaten Tulang Bawang.

$\mathrm{H}_{\mathrm{a}}$ : Disiplin Kerja (X1) dan Sarana Prasarana (X2) berpengaruh secara simultan terhadap Produktivitas kerja (Y) Dinas Perikanan Kabupaten Tulang Bawang.

Berikut hasil analisis dari software SPSS:

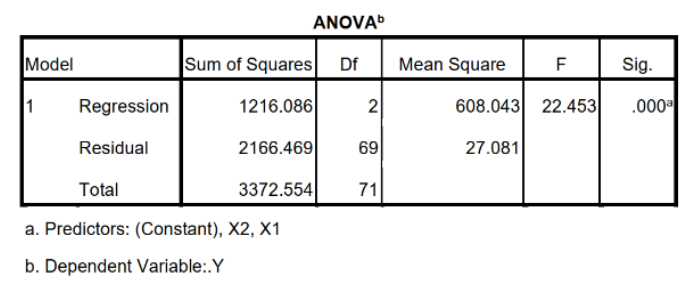

Gambar 6. Pengujian Hipotesis secara simultan Disiplin Kerja dan Sarana Prasarana terhadap Produktivitas Kerja

Berdasarkan Gambar 6 di atas, diperoleh nilai $\mathrm{Sig}=0,001<0,05 . \mathrm{H}_{\mathrm{o}}$ ditolak dan $\mathrm{H}_{\mathrm{a}}$ diterima, yang artinya Disiplin Kerja (X1) dan Sarana Prasarana (X2) berpengaruh secara simultan terhadap Produktivitas kerja (Y) Dinas Perikanan Kabupaten Tulang Bawang.

Seberapa besar pengaruh variabel disiplin kerja dan sarana prasarana dalam menjelaskan variabel produktivitas kerja dapat dilihat dari nilai koefisien determinasi ( $R$ Square) pada gambar berikut ini.

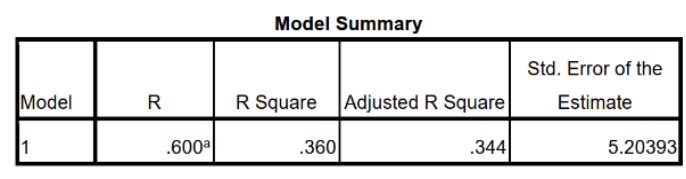

a. Predictors: (Constant),X2,X1

Gambar 7. Hasil Uji Koefisien Determinasi
Gambar 7 di atas menjelaskan bahwa $R$ Square sebesar 0.360 yang artinya sebesar $36 \%$ variasi perubahan variabel produktivitas kerja mampu dijelaskan oleh variabel Disiplin Kerja dan Sarana Prasarana sedangkan sisanya yaitu 64\% lagi dijelaskan faktor-faktor lain yang tidak diteliti dalam penelitian ini.

\section{PENUTUP}

Dari Hasil dan Pembahasan di atas di dapat kesimpulan antara lain: 1) Disiplin kerja berpengaruh positif terhadap produktivitas kerja pegawai pada Dinas Perikanan Kabupaten Tulang Bawang dengan kontribusi sebesar 32,8\%; 2) Sarana prasarana berpengaruh positif terhadap produktivitas kerja pegawai pada Dinas Perikanan Kabupaten Tulang Bawang dengan kontribusi sebesar $13,7 \%$, dan 3) Disiplin kerja dan sarana prasarana secara bersama-sama berpengaruh positif terhadap produktivitas kerja pegawai Dinas Perikanan Kabupaten Tulang Bawang dengan kontribusi sebesar 36\%, sisanya sebesar $64 \%$ merupakan pengaruh variabel lain di luar penelitian ini.

Dari kesimpulan yang didapat, maka terdapat beberapa saran, antara lain : 1) Untuk perbaikan tingkat disiplin kerja pegawai dapat terfokus pada aspek kepatuhan dan tanggung jawab. Untuk itu dibutuhkan ketegasan dari unsur pimpinan dalam memberikan sanksi kepada pegawai yang melakukan tindakan indisipliner, untuk memberikan efek jera di kemudian hari; 2) Untuk mengatasi kendala sarana prasarana, di masa yang akan datang perlu diajukan anggaran peremajaan dan atau pengadaan kendaraan dinas dengan kuantitas yang menyesuaikan kebutuhan; dan 3) Upaya meningkatkan produktivitas kerja pegawai dapat berfokus kepada aspek kualitas, terutama pada pencapaian target 
sasaran kinerja pegawai. Untuk itu unsur pimpinan dapat lebih menjalankan fungsi supervisi-nya yaitu terfokus kepada pengawasan terhadap proses pelaksanaan pekerjaan untuk memastikan segala kegiatan yang tertuju kepada pencapaian tujuan telah berjalan sesuai dengan perencanaan.

\section{DAFTAR PUSTAKA}

Adha, R. N., Qomariah, N., \& Hafidzi, A. H. (2019). Pengaruh Motivasi Kerja, Lingkungan Kerja, Budaya Kerja Terhadap Kinerja Karyawan Dinas Sosial Kabupaten Jember. Jurnal Penelitian IPTEKS, 4(1), 47. https://doi.org/10.32528/ipteks.v4i1.2 109

Adiwilaga, R. (2019). Disiplin Pegawai Sebagai Upaya Menekan Patologi Birokrasi di Dinas Binamarga Sumber Daya Air dan Pertambangan Kabupaten bandung Barat. Journal of Government Civil Society, 3(2), 139152.

Alexander, D. (2020). Upaya Administratif Atas Pelanggaran Kewajiban dan Larangan Menurut Peraturan Pemerintah Nomor 53 Tahun 2010 tentang Disiplin Pegawai Negari Sipil. Lex Administratum, 8(3), 169177.

Amaliah, H. N. (2019). Sarana Prasarana Kantor Sebagai Penunjang Produktivitas Kantor Yang Efektif Dan Efisien. Jurnal Manajemen Kantor.

Andini, Y., Lubis, Y., \& Siregar, R. S. (2019). Pengaruh Disiplin Kerja Terhadap Produktivitas Kerja Karyawan PT Perkebunan Nusantara IV (Persero) Unit Usaha Pabatu. Jurnal Agriuma, 1(2), 68-77. https://doi.org/10.31289/agr.v1i2.287 4

Bili, W., Resmawan, E., \& Kondorura, D.
(2018). Pengaruh Pengalaman Kerja Terhadap Kinerja Pegawai di kantor Kecamatan Laham Kabupaten Mahakam Ulu. E-Journal Pemerintahan Integratif, 6(3), 465474.

Daulay, R., Kurnia, E., \& Maulana, I. (2019). Analisis Faktor-Faktor Yang Mempengaruhi Kinerja Karyawan Pada Perusahaan Daerah di Kota Medan. Proseding Seminar Nasional Kewirausahaan, 1(1), 209-218.

Dewi, I., Mustakin, \& Liwaul. (2018). Faktor-Faktor Yang Mempengaruhi Disiplin Kerja Pegawai Pada Sekretariat Daerah (Setda) Kabupaten Buton Tengah. Jurnal Administrasi Publik, 4(2), 1689-1699. http://ojs.uho.ac.id/index.php/rezpubli ca/article/view/13

Effendy, A. A., \& Fitria, J. R. (2020). Pengaruh Gaya Kepemimpinan, Motivasi Dan Disiplin Kerja Terhadap Kinerja Karyawan (Studi Kasus PT. Modernland Realty, TBK). JENIUS (Jurnal Ilmiah Manajemen Sumber Daya Manusia), 3(3), 264. https://doi.org/10.32493/jjsdm.v3i3.4 864

Ellong, T. D. A. (2018). Manajemen Sarana dan Prasarana di Lembaga Pendidikan Islam. Jurnal Ilmiah Iqra', 11(1). https://doi.org/10.30984/jii.v11i1.574

Fithri, P., \& Sari, R. Y. (2016). Analisis Pengukuran Produktivitas Perusahaan Alsintan CV. Cherry Sarana Agro. Jurnal Optimasi Sistem Industri, 14(1),

138. https://doi.org/10.25077/josi.v14.n1.p 138-155.2015

Hadi, S., \& Abdurrahman, A. (2019). Pengaruh Sarana Kerja, dan Kemampuan Terhadap Kinerja Aparatur Kelurahan Landasan Ulin Selatan Kota Banjarbaru. Administraus - Jurnal Ilmu Administrasi Dan Manajemen, 3(3), 
57-92.

Hartanto, Hendriani, S., \& Maulida, Y. (2018). Analisis pengaruh kondisi kerja, motivasi kerja, dan disiplin kerja terhadap kinerja pegawai kantor wilayah direktorat jenderal kekayaan Negara Riau, Sumatera Barat, dan Kepulauan Riau. Tepak Manajemen Bisnis, 10(2), 226-241.

Hassan, H., Mangare, J. B., \& Pratasis, P. A. K. (2016). Faktor-Faktor Penyebab Keterlambatan Pada Proyek Konstruksi dan Alternatif Penyelesaiannya (Studi Kasus: di Manado Town Square III). Jurnal Sipil Statik, 4(11), 657-664.

Herdin, A. R. P., \& Suyitno, I. (2016). Penerapan Peraturan Disiplin PNS Dalam Rangka Peningkatan Kinerja di Kantor Kecamatan Biringkanaya Kota Makassar. Jurnal Tomalebbi, 1, 44-51.

Husna, N. (2017). Pengaruh Disiplin Kerja Terhadap Kinerja Guru Pada SMAN 1 Canduang Kabupaten Agam. Jurnal EKOBISTEK Fakultas Ekonomi, 6(2), 286-298.

http://lppm.upiyptk.ac.id/ojsupi/index .php/EKOBISTEK

Jannah, A., Fitria, B. T., \& Hadiat, E. (2014). Pengaruh Kompensasi, Pengembangan Karier, dan Disiplin Kerja Terhadap Kinerja Pegawai Dinas Pendapatan Daerah Kota Cimahi. Jurnal Ekonomi, Bisnis, \& Entrenpreneurship, 8(2), 99-110.

Kamal, M. B. (2015). Pengaruh kepemimpinan dan Pengawasan Terhadap Disiplin Kerja Karyawan Pada PT. Perkebunan Nusantara III (Persero). Jurnal Ilmiah Manajemen Dan Bisnis, 15(1), 61-70.

Karollah, B. (2017). Pengaruh Remunerasi Terhadap Kinerja Pegawai Balai Pengelolaan Daerah Aliran Sungai dan Hutan Lindung Krueng Aceh. SIMEN (Akuntansi Dan Manajemen)
STIES, 8(1), 1-21.

Mahrita, Arifin, J., \& Arbayah, S. (2018). Analisis Disiplin Kerja (Aparatur Sipil Negara) pada Dinas Kependudukan dan Pencatatan Sipil berdasarkan PP 53 Tahun 2010 Kabupaten Tabalong. JAPB, 1(1), 290-304.

Ningrum, E. (2016). Pengembangan Sumber Daya Manusia Bidang Pendidikan. Jurnal Geografi Gea, 9(1).

https://doi.org/10.17509/gea.v9i1.168 1

Ningrum, M. E. (2013). Peranan Komunikasi Internal Di Lingkungan Kerja. Indept, 3(1), 25-30.

Nisa, I. C. (2017). Pengaruh Kualitas Sumber Daya Manusia dan Sarana Prasarana Terhadap Produktivitas Kinerja Pegawai di Kantor Pengadilan Agama Kelas 1B Kabupaten Sukoharjo. In Universitas Sebelas Maret. Universitas Sebelas Maret.

Nooraeni, R. (2017). Implementasi Program Parenting Dalam Menumbuhkan Perilaku Pengasuhan Positif Orang Tua Di PAUD Tulip Tarogong Kaler Garut. Jurnal Pendidikan Luar Sekolah, 13(2), 31-41.

Prianto, A., Kurniati, I., Wahyudi, M. T., \& Yulistia, E. (2020). Berbagai Faktor Penentu Kesiapan Untuk Berubah dan Pengaruhnya Terhadap Keberlangsungaan Kegiatan UMKM di Wilayah Terdampak Wabah Covid19. Jurnal Ekonomi Dan Manajemen, 4(1), 14-42.

Purwati, Y., \& Nugraha, J. T. (2018). Pengaruh Gaya Kepemimpinan dan Motivasi Kerja Terhadp Kinerja Pegawai ( Studi Pada Kantor Kelurahan Kedungsari, Magelang Utara ). Jurnal Mahasiswa Administrasi Negara (JMAN), 2(1), 84-95. 
http://jom.untidar.ac.id/index.php/jma n/article/view/225

Putri, A. K., \& Sukirno. (2020). Disiplin Kerja Staf Unit Sekretaris Perusahaan di Perusahaan Umum Jaminan Kredit Indonesia. Jurnal Mahasiswa Bina Insani, 4(2), 165-174.

Radito, T. A. (2016). Analisis Pengaruh Disiplin Kerja, Lingkungan Kerja, Dan Jaminan Sosial Terhadap Produktivitas Kerja Pegawai. Jurnal Bisnis Manajemen, 3(2), 12-25.

Rakhman, A. F. (2019). Perancangan Sarana Permainan Untuk Wahana Geared Up di Dago Dream Park dengan Aspek Teori Struktur dan Sistem. E-Proceeding of Art \& Design, 6(2), 2747-2756.

Richiyanti, S. (2019). Penyalahgunaan Mobil Dinas Dalam Kaitannya Dengan Tindak Pidana Korupsi. Kodifikasi, 1(1), 141-152.

Riyanto, A. (2019). Disiplin Kerja Guru Dalam Proses Belajar Mengajar Di SMP IT Istiqomah Bengkulu. Ahsanta Jurnal Pendidikan, 5(3), 50 55.

Saleh, A. R., \& Utomo, H. (2018). Pengaruh Disiplin Kerja, Motivasi Kerja, Etos Kerja Dan Lingkungan Kerja Terhadap Produktivitas Kerja Karyawan Bagian Produksi Di Pt. Inko Java Semarang. Among Makarti, 11(1), $28-50$. https://doi.org/10.52353/ama.v11i1.1 60

Sandiani, N. L., Suryawan, I. G. B., \& Widiati, I. A. P. (2020). Penegakan Sanksi Terhadap Aparatur Sipil Negara yang Melakukan Pelanggaran Disiplin di Lingkungan Pemerintah Kota Denpasar. Jurnal Interpretasi Hukum, 1(1), 196-203. https://doi.org/10.22225/juinhum.1.1. 2210.196-203

Saputra, A., \& Turnip, R. R. (2018). Pengaruh Motivasi, Komunikasi Dan
Disiplin Terhadap Kepuasan Kerja PT PLN (Persero) P3B Sumbagut. Jurnal Manajemen Bisnis, 29(2), 1-8. https://doi.org/10.31227/osf.io/8zq7m

Saputra, N., \& Mulia, R. A. (2020). Kontribusi Kompensasi dan Motivasi Kerja Terhadap Kepuasan Kerja Pegawai di Dinas Pendidikan dan Kebudayaan Kabupaten Agam. Ensiklopedia Social Review, 2(1), 20 28.

https://doi.org/10.31227/osf.io/6hxwk Sholiha, M., Sunaryo, H. H., \& Priyono, A. A. (2017). Pengaruh Kecerdasan Emosional Dan Kecerdasan Spiritual Terhadap Kinerja Guru SMP An-Nur Bululawang-Malang. Warta Ekonomi, 7(17), 78-92.

Sulastriningsih, K., \& Novita, A. (2016). Pengaruh Kemampuan dan Motivasi Kerja Petugas Kesehatan Terhadap Kinerja Dalam Penerapan Program Manajemen Terpadu Balita Sakit di Puskesmas Pasar Minggu. Jurnal Akademi Keperawatan Husada Karya Jaya, 2(1), 3-12.

Sulistya, H., \& Zain, R. (2020). Hubungan Pengelolaan Sarana dan Prasarana Berbasis IT Terhadap Peningkatan Produktivitas Kerja Pegawai (Studi Kasus di Kementerian Agama Kabupaten Kulon Progo). Evaluasi, 4(2), 290-316.

Suryani, I., \& Maulana, Y. S. (2019). Analisis Disiplin Kerja Dalam Meningkatkan Produktivitas Karyawan. ABDIS: Jurnah Ilmiah Administrasi Bisnis, 4(1), 14-24.

Tanjung, H. (2015). Pengaruh Disiplin Kerja dan Motivasi Kerja Terhadap Prestasi Kerja Pegawai Pada Dinas Sosial dan tenaga Kerja Kota Medan. Jurnal Ilmiah Manajemen Dan Bisnis, 15(1), 27-36.

Wijayanti, D. P., \& Sundiman, D. (2017). Pengaruh Knowledge Management Terhadap Kinerja Karyawan (Studi 
Empiris Pada PT. SMS Kabupaten Kotawaringin Timur). DeReMa Jurnal Manajemen, 12(1), 69-85.

Yanti, Haryono, A. T., \& Minarsih, M. M. (2015). Pengaruh Kompensasi, Motivasi Kerja, Lingkungan Kerja dan Disiplin Terhadap Kinerja Karyawan pada CV Koperasi Puri Kencana Taxi Semarang. Journal of Management, $\quad 1(1), \quad 1-23$. http://jurnal.unpand.ac.id/index.php/ MS/article/view/271 